\title{
Patient-Reported Outcomes in Rheumatoid Arthritis: Why are They Important and How Should They Be Assessed?
}

\author{
Romatoid Artrit'te Hasta ilişkili Sonuç Parametreleri: Neden Önemli ve \\ Nasıl Değerlendirmeli?
}

Laure Gossec

Service de Rhumatologie B, Hôpital Cochin, 27, rue du faubourg Saint-Jacques, Paris, France

\section{Abstract}

Patient reported outcomes have become increasingly important in the evaluation of rheumatoid arthritis (RA) over recent years. Besides pain and functional capacity, fatigue, sleep and wellbeing are also important for RA patients. We will discuss here the importance of patient-reported outcomes, different domains of health, and how to evaluate them, with a focus on questionnaires available in Turkey.

(Turk J Rheumatol 2010; 25: 99-104)

Key words: Rheumatoid arthritis, outcome measure, response criteria, fatigue, pain

Received: 20.06.2010
Accepted: 05.07.2010

\section{Özet}

Son yıllarda romatoid artritin (RA) değerlendiriminde hasta ilișkili sonuc parametreleri giderek daha fazla önem kazanmıștır. Ağrı ve fonksiyonel kapasite haricinde yorgunluk, uyku ve iyilik de RA'lı hastalar için önemlidir. Bu derlemede hasta ilișkili sonuc parametreleri ve sağlığın farklı alanlarının önemini, nasıl değerlendirileceğini Türkiye'de kullanılan anketlere odaklanarak tartıșacağız. (Turk J Rheumatol 2010; 25: 99-104)

Anahtar sözcükler: Romatoid artrit, sonuç parametresi, cevap kriterleri, yorgunluk, ağrı

Alındığı Tarih: 20.06.2010 Kabul Tarihi: 05.07.2010

\section{Introduction}

Rheumatoid arthritis (RA) is traditionally assessed by physical examination by a physician, by laboratory tests and radiographs, in keeping with a "biomedical model," the dominant paradigm of $20^{\text {th }}$-century medicine. However, since the start of the new millennium, there has been growing interest in assessment of RA from the patient's perspective (1).

In this article, we will discuss the importance of patient reported outcomes (PROs), the different domains or dimensions of health important for patients with RA, and the questionnaires available to assess PROs.

\section{Why should we assess PROs?}

There are several arguments in favour of assessing PROs.

\section{A. Assessing the patients' perspective}

For the purpose of preventing joint destruction in RA, it is important to be able to detect inflammation, i.e. synovitis and acute phase reactants since these elements

Address for Correspondence: Dr. Laure Gossec, Service de Rhumatologie B, Hôpital Cochin, 27, rue du faubourg Saint-Jacques, 75014 Paris Phone: 33- 158412606 Fax: 33- 143549256 E- mail: laure.gossec@cch.aphp.fr 
seem closely correlated to further bone erosions (2). However, it is not sufficient to monitor these objective elements reflecting inflammation. Indeed, RA is also a disease which leads to a considerable burden of disease for patients, i.e. to symptoms such as pain and functional disability. Since the final objective of treatment is in fact better health-related quality of life (3), monitoring patients' symptoms is necessary in RA, as it is in other chronic diseases which impact quality of life, if we want to be able to assess the efficacy of our treatments. This is particularly important since the patient's perspective on outcomes is different from the physician's perspective, in RA (Figure 1).

\section{B. PROs bring interesting and valuable data}

They have no cost and are non invasive. They have good psychometric properties: some PROs have been found to be as informative as joint counts, radiographic and laboratory data for the assessment of baseline status, change during interventions, and are predictive of longterm outcomes (4-6). This is particularly true for the Health Assessment Questionnaire, HAQ.

\section{In clinical trials}

Pros give us the patients' assessment of efficacy of treatment, which is important when taking therapeutic decisions. Assessment of PROs is also mandatory for the obtention of drug licensing (for the Food and Drug Administration). Finally, assessment of quality of life (using generic instruments) allows comparisons across diseases, necessary for economic analyses.

\section{In clinical practice}

Of course, assessing PROs during an outpatient clinic takes time. However, we still believe it is important to assess PROs. Assessing patient global allows the calculation of the disease activity score (DAS); we suggest that a visual analog scale (VAS) for pain and fatigue should also be assessed, as well as morning stiffness. By such a standardised assessment, we obtain the patients' assessment of efficacy of treatment, and we can positively influence the patient-physician relationship since the patient feels listened to. We do not suggest that fatigue will influence disease-modifying decisions, but other therapeutic modalities (physical therapy, anti-depressant drugs ...) can be prescribed if needed.

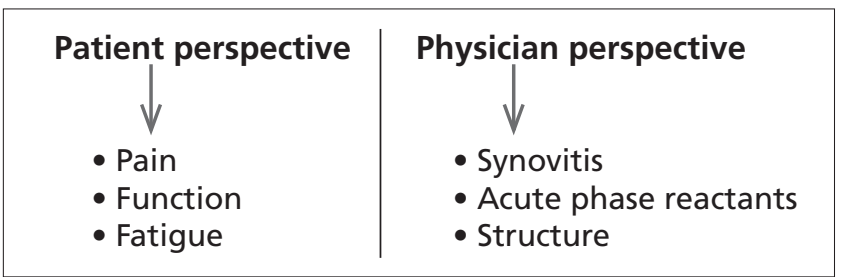

Figure 1. Illustration of the different perspectives in RA

\section{Different PROs in RA}

\section{A. Some PROs are frequently assessed}

Since 1993, assessment of the activity of RA has become standardised, after the elaboration of a 'Core Set' of domains or dimensions which have become mandatory to report in trials. The 'Core Set' is used both in Europe and in the United States since it is recognised both by the American College of Rheumatology (ACR) $(7,8)$ and the European League Against Rheumatism (EULAR) (9), (Table 1). In the 'Core Set', 3 elements pertain to the patients' perspective; these elements are pain, functional capacity and patient global assessment. These elements are usually reported in trials, as shown by Dr Kalyoncu from Ankara (10): more than half of the studies recently published in $\mathrm{RA}$, reported these outcomes.

\section{B. Other PROs are rarely assessed}

Several publications issued from patient group discussions $(11,12)$ or patient focus groups $(13)$ indicate that some domains or areas of health which are important for patients are unrecognised and underestimated in RA. These domains include, among others, fatigue $(11,13,14)$, well-being $(11,13,14)$, sleep patterns (11), work incapacity (13) or return to normal

\section{Table 1. The 'Core Set' in RA \\ Painful joint count \\ Synovial joint count \\ Acute phase reactants \\ Global assessment (doctor) \\ Pain (assessed by patient) \\ Global assessment (patient) \\ Functional capacity (patient)}

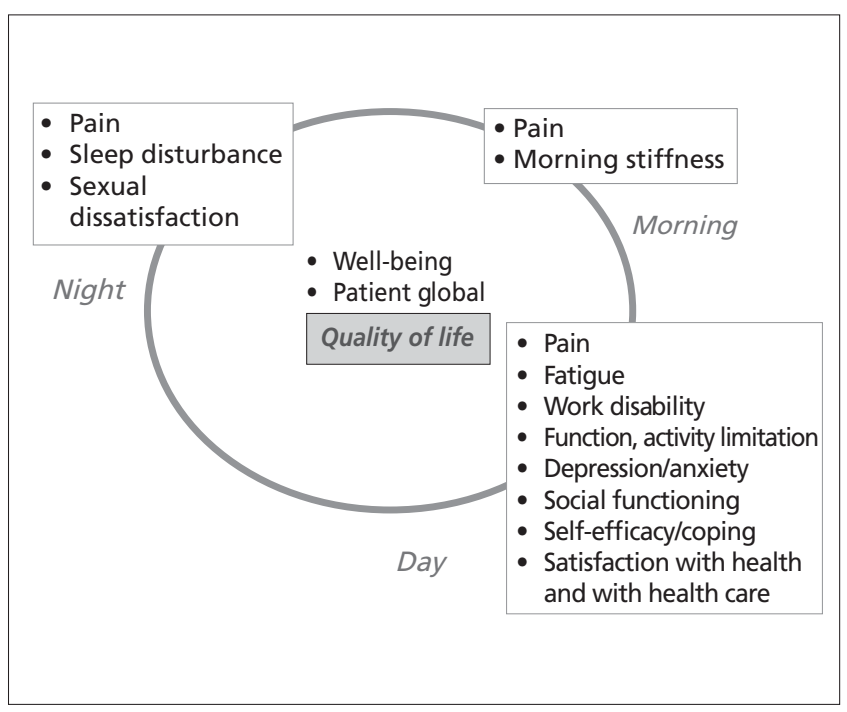

Figure 2. Domains of health which are important in RA 
life $(13,14)$ and independence (i.e. being able to manage daily activities such as personal hygiene) (13). PROs in RA are synthesized Figure 2. Most of the domains important for patients are rarely reported in publications (10).

\section{Description of some of the domains of health in} PROs (15)

A. Pain, functional capacity and patient global assessment

Pain and functional disability are part of the RA Core Set (7) and are regularly cited by people with RA as important (11-16).

Pain VAS is considered as the gold standard to assess pain (17). Because of its simplicity, VAS is a useful method of assessment for PROs. However, there are some limits to the use of VAS. Elderly persons, lowliteracy populations, and some cultural groups have difficulties conceptualizing a VAS. In these cases, numerical rating scales may be a useful alternative. Giving the patient the opportunity to rate himself in comparison to a previous rating may also be helpful. An important element is that a VAS or numerical rating scale is very quick and easy to apply and can also be used as part of daily clinical practice.

The HAQ and the shorter, modified-HAQ are easy to administer self-questionnaires which comprise 8 categories of functioning: dressing, rising, eating, walking, hygiene, reach, grip, and usual activities $(18,19)$.

Global assessment is usually assessed with a VAS but the wording varies widely (10).

\section{B. Fatigue}

Fatigue was poorly recognised before 2003 (11). Since that date, several qualitative studies $(13,14)$ have pointed out the importance of fatigue for patients with RA; fatigue is intrusive and overwhelming in RA according to patients, and has consequences on all aspects of quality of life.

Fatigue VAS is a single-item scale. It measures the severity of fatigue over the past week with a specific question (20). Fatigue VAS is simple and reproducible, and the validated wording is included in Table 2 .

\section{Other domains}

Other domains reported in the literature as important include well-being, sleep disturbance, coping, social life, professional status (ability to work) and satisfaction with health care $(11-14,16)$.

Morning stiffness is often assessed, reflecting the inflammatory component of pain, but is not highly sensitive to change.

\section{Multi-domain assessments}

\section{A. Quality of life}

Health-related quality of life assesses in fact several aspects of RA. It is frequently assessed by the SF36 (21). Composite scores which are patient reported include the patient activity scale (PAS) (22), the Routine Assessment of Patient Index Data 3 (RAPID3) (23) et the recently published European League Against Rheumatism tool, the Rheumatoid Arthritis Impact of Disease (RAID) (1). The first 2 criteria integrate the 3 domains usually assessed in RA, namely, pain, function and patient global.

\section{B. The RAID}

Under the aegis of EULAR, the European League Against Rheumatism, an international task force elaborated a new composite response score for clinical trials in RA, based on the patients' perception of the impact of the disease on domains of health: the patientderived preliminary RA Impact of Disease (RAID) score (1). The score includes 7 domains prioritised by patients. The domains of highest importance are pain, functional disability, and fatigue; the 4 other domains are emotional and physical well-being, sleep disturbance and coping (Table 2). The RAID has been elaborated and validated with the participation of Turkey (Dr. Gogus and Dr. Gunendi) therefore this score can be used in Turkish (Table 3). The RAID is viewed as an additional instrument for the assessment of RA, giving supplementary information on patient-relevant domains.

\section{Conclusion}

In conclusion, assessment of PROs is increasingly important in RA. PROs capture information which is relevant for the patients although their value for treatment-modifying decisions remains to be established. Fatigue should be taken into account in RA and treatments which are efficacious for RA-related fatigue should be assessed.

However, further work is needed in PROs: which ones are of greatest interest according to the underlying cultural background, how to find the validated questionnaires, prognostic value of PROs, cutoffs defining patient acceptable symptom states and clinically relevant improvement, PROs in other diseases. The European League Against Rheumatism is planning to finance future studies in PROs in the next years, so we may obtain some of these answers soon!

\section{Conflict of Interest}

No conflict of interest is declared by author. 
Table 2. The RAID score, a composite score to capture impact of RA (1)

RAID questionnaire
1. Pain
Circle the number that best describes the pain you felt due to your rheumatoid arthritis during the last week:
None
\begin{tabular}{|c|c|c|c|c|c|c|c|c|c|c|}
\hline 0 & 1 & 2 & 3 & 4 & 5 & 6 & 7 & 8 & 9 & 10 \\
Extreme
\end{tabular}

2. Functional disability assessment

Circle the number that best describes the difficulty you had in doing daily physical activities due to your rheumatoid arthritis during the last week.

\begin{tabular}{|c|c|c|c|c|c|c|c|c|c|c|c|c|}
\hline No difficulty & 0 & 1 & 2 & 3 & 4 & 5 & 6 & 7 & 8 & 9 & 10 & Extreme difficulty \\
\hline
\end{tabular}

\section{Fatigue}

Circle the number that best describes how much fatigue you felt due to your rheumatoid arthritis during the last week.

No fatigue

\begin{tabular}{|l|l|l|l|l|l|l|l|l|l|l|}
\hline 0 & 1 & 2 & 3 & 4 & 5 & 6 & 7 & 8 & 9 & 10 \\
\hline
\end{tabular}

Totally exhausted

4. Sleep

Circle the number that best describes the sleep difficulties (i.e., resting at night) you felt due to your rheumatoid arthritis during the last week.

No difficulty

\begin{tabular}{|l|l|l|l|l|l|l|l|l|l}
\hline 0 & 1 & &
\end{tabular}

\begin{tabular}{l|l|l}
2 & 3 & 4
\end{tabular}

\begin{tabular}{|l|l|l|l|l}
5 & & & \\
\hline
\end{tabular}

\begin{tabular}{l|l|l}
6 & 7
\end{tabular}

\begin{tabular}{|l|l|l|}
\hline 8 & 9 & 10 \\
\hline
\end{tabular}

Extreme difficulty

\section{Physical well-being}

Considering your arthritis overall, how would you rate your level of physical well being during the past week? Circle the number that best describes your level of physical well-being.

Very good

\begin{tabular}{|l|l|l|l|l|l|l|l|l|l|l|}
\hline 0 & 1 & 2 & 3 & 4 & 5 & 6 & 7 & 8 & 9 & 10 \\
\hline
\end{tabular}

\section{Emotional well-being}

Considering your arthritis overall, how would you rate your level of emotional well being during the past week? Circle the number that best describes your level of emotional well-being.

Very good

\begin{tabular}{|l|l|l|l|l|}
\hline 0 & 1 & 2 & 3 \\
\hline
\end{tabular}

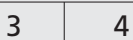

\section{Coping}

Considering your arthritis overall, how well did you cope ( manage, deal, make do) with your disease during the last week?

Very well

\begin{tabular}{|l|l|l|l|l|l|l|l|l|l|l|}
\hline 0 & 1 & 2 & 3 & 4 & 5 & 6 & 7 & 8 & 9 & 10 \\
\hline
\end{tabular}

\section{RAID SCORING AND CALCULATION RULES}

The RAID is calculated based on 7 Numerical rating scales (NRS) questions. Each NRS is assessed as a number between 0 and 10 . The 7 NRS correspond to pain, function, fatigue, sleep, emotional well-being, physical well-being, and coping/self-efficacy.

1. Calculation

RAID final value $=$

(pain NRS value (range $0-10) \times 0.21)+($ function NRS value (range $0-10) \times 0.16)+($ fatigue NRS value (range $0-10) \times 0.15)+($ phys well being NRS value (range $0-10) \times 0.12$ ) + (sleep NRS value (range $0-10) \times 0.12$ ) + (emotional well being NRS value (range $0-10) \times 0.12)+($ coping NRS value $($ range $0-10) \times 0.12$ )

Thus, the range of the final RAID value is $0-10$ where higher figures indicate worse status

2. Missing data imputation

If one of the 7 NRS values composing the RAID is missing, the imputation is as follows:

a. calculate the mean value of the 6 other (non-missing) NRS (range, 0-10)

b. impute this value for the missing NRS

c. Then, calculate the RAID as explained above

If 2 or more of the NRS are missing, the RAID is considered as missing value (no imputation) 
Table 3. The RAID is validated in Turkish (1)

\section{Ağrı}

Geçen hafta romatoid artritinize bağlı hissettiğiniz ağrıyı en iyi tarif eden rakamı yuvarlak içine alınız.

Yok

\begin{tabular}{|l|l|l|l|l|l|l|l|l|l|l|}
\hline 0 & 1 & 2 & 3 & 4 & 5 & 6 & 7 & 8 & 9 & 10 \\
\hline
\end{tabular}

\section{2. İslevsel özürlülük değerlendirimi}

Geçen hafta romatoid artritinize bağlı günlük fiziksel aktivitelerinizi yapmakta çektiğiniz güçlüğü en iyi tarif eden rakamı yuvarlak içine alınız.

Zorluk yok

\begin{tabular}{|l|l|l|l|l|l|l|l|l|l|l|}
\hline 0 & 1 & 2 & 3 & 4 & 5 & 6 & 7 & 8 & 9 & 10 \\
\hline
\end{tabular}

Așırı zorluk

\section{Yorgunluk}

Geçen hafta romatoid artritinize bağlı ne kadar yorgunluk hissetiğinizi en iyi tarif eden rakamı yuvarlak içine alınız.

\begin{tabular}{|c|c|c|c|c|c|c|c|c|c|c|c|c|}
\hline Yorgunluk yok & 0 & 1 & 2 & 3 & 4 & 5 & 6 & 7 & 8 & 9 & 10 & $\begin{array}{l}\text { Tamamen bitap } \\
\text { düsmüs }\end{array}$ \\
\hline
\end{tabular}

\section{Uyku}

Geçen hafta romatoid artritinize bağlı hissetiğiniz uyku güçlüklerini (ör. gece dinlenirken) en iyi tarif eden rakamı yuvarlak içine alınız.

Zorluk yok

\begin{tabular}{|l|l|l|l|l|l|l|l|l|l|l|}
\hline 0 & 1 & 2 & 3 & 4 & 5 & 6 & 7 & 8 & 9 & 10 \\
\hline
\end{tabular}

Așırı zorluk

\section{Fiziksel iyilik}

Genel olarak hastalığınızı göz önüne aldığınızda, geçen haftaki fiziksel iyilik halinizi nasıl değerlendirirsiniz? Fiziksel iyilik halinizi en iyi tarif eden rakamı yuvarlak içine alınız.

Cok iyi

\begin{tabular}{|l|l|l|l|l|l|l|l|l|l|l|}
\hline 0 & 1 & 2 & 3 & 4 & 5 & 6 & 7 & 8 & 9 & 10 \\
\hline
\end{tabular}

\section{Duygusal iyilik}

Genel olarak hastalığınızı göz önüne aldığınızda geçen haftaki duygusal iyilik halinizi nasıl değerlendirirsiniz? Duygusal iyilik halinizi en iyi tarif eden rakamı yuvarlak içine alınız.

Cok iyi

\begin{tabular}{|l|l|l|l|l|l|l|l|l|l|l|}
\hline 0 & 1 & 2 & 3 & 4 & 5 & 6 & 7 & 8 & 9 & 10 \\
\hline
\end{tabular}

\section{Bașa çıkabilme}

Genel olarak hastalığınızı göz önüne aldığınızda geçen hafta hastalığınızla nasıl bașa çıkabildiniz? (idare etmek, dayanmak)

Çok kötü

\begin{tabular}{|l|l|l|l|l|l|l|l|l|l|l|}
\hline 0 & 1 & 2 & 3 & 4 & 5 & 6 & 7 & 8 & 9 & 10 \\
\hline
\end{tabular}




\section{References}

1. Gossec L, Dougados M, Rincheval N, Balanescu A, Boumpas DT, Canadelo $S$, et al. Elaboration of the preliminary Rheumatoid Arthritis Impact of Disease (RAID) score: a EULAR initiative. Ann Rheum Dis. 2009 Nov; 68(11): 1680-5.

2. Sokka $\mathrm{T}$, Kautiainen $\mathrm{H}$, Mottonen $\mathrm{T}$, Hannonen P. Erosions develop rarely in joints without clinically detectable inflammation in patients with early rheumatoid arthritis. J Rheumatol 2003; 30: 2580-4.

3. Smolen JS, Landewé R, Breedveld FC, Dougados M, Emery $P$, Gaujoux-Viala $C$, et al. EULAR recommendations for the management of rheumatoid arthritis with synthetic and biological disease-modifying antirheumatic drugs. Ann Rheum Dis 2010; 69: 964-75.

4. Wolfe F, Cathey MA. The assessment and prediction of functional disability in rheumatoid arthritis. J Rheumatol 1991; 18: 1298-306.

5. Söderlin MK, Nieminen P, Hakala M. Functional status predicts mortality in a community based rheumatoid arthritis population. J Rheumatol 1998; 25: 1895-9.

6. Sokka T, Hakkinen A, Krishnan E, Hannonen P. Similar prediction of mortality by the health assessment questionnaire in patients with rheumatoid arthritis and the general population. Ann Rheum Dis 2004; 63: 494-7.

7. Felson DT, Anderson JJ, Boers M, Bombardier C, Chernoff M, Fried $\mathrm{B}$, et al. The American College of Rheumatology preliminary core set of disease activity measures for rheumatoid arthritis clinical trials. The Committee on Outcome Measures in Rheumatoid Arthritis Clinical Trials. Arthritis Rheum 1993; 36: 729-40.

8. Saag KG, Teng GG, Patkar NM, Anuntiyo J, Finney C, Curtis $J R$, et al. American College of Rheumatology 2008 recommendations for the use of nonbiologic and biologic disease-modifying antirheumatic drugs in rheumatoid arthritis. Arthritis Rheum 2008; 59: 762-84.

9. Boers $M$, Tugwell $P$, Felson $D T$, van Riel PL, Kirwan JR, Edmonds JP, et al. World Health Organization and International League of Associations for Rheumatology core endpoints for symptom modifying antirheumatic drugs in rheumatoid arthritis clinical trials. J Rheumatol Suppl. 1994; 41: 86-9.

10. Kalyoncu U, Dougados M, Daurès JP, Gossec L. Reporting of patient-reported outcomes in recent trials in rheumatoid arthritis: a systematic literature review. Ann Rheum Dis 2009; 68: 183-90.

11. Kirwan J.R., Heiberg T, Hewlett SA. Outcomes from the Patient Perspective Workshop at OMERACT 6. J Rheumatol 2003;30:868-72.

12. Kirwan J.R, Hewlett S.E, Heiberg T, Hughes R.A, Carr M, Hehir M. et al. Incorporating the Patient Perspective into
Outcome Assessment in Rheumatoid Arthritis- Progress at OMERACT 7. J Rheumatol 2005;32:2250-6.

13. Ahlmen, U. Nordenskiöld, B. Archenholtz, I. Thyberg, R. Rönnqvist, L. Linden, A.-K. Andersson and K. Mannerkopi. Rheumatology outcomes: the patient's perspective. A multicentre focus group interview study of Swedish rheumatoid arthritis patients. Rheumatology 2005; 44: 105-10.

14. Carr A, Hewlett S, Hughes R, Mitchell H, Ryan S, Carr M, Kirwan J. Rheumatology outcomes: the patient's perspective. J Rheumatol 2003; 30: 880-3.

15. Katz P. Introduction to Special Patient Outcomes in Rheumatology Issue of Arthritis Care \& Research. Arthritis Rheum 2003; 49: 1-4.

16. Heiberg T, Kvien TK. Preferences for improved health examined in 1,024 patients with rheumatoid arthritis: pain has highest priority. Arthritis Rheum 2002; 47: 391-7.

17. Carol S. Burckhardt, Kim D. Jones. Adult Measures of Pain The McGill Pain Questionnaire (MPQ), Rheumatoid Arthritis Pain Scale (RAPS), Short-Form McGill Pain Questionnaire (SF-MPQ), Verbal Descriptive Scale (VDS), Visual Analog Scale (VAS), and West Haven-Yale Multidisciplinary Pain Inventory (WHYMPI). Arthritis \& Rheumatism (Arthritis Care \& Research) 2003; 49: 96-104.

18. Fries JF, Spitz PW, Young DY. The dimensions of health outcomes: the health assessment questionnaire, disability and pain scales. J Rheumatol 1982; 9: 789-93.

19. Pincus T, Summey JA, Soraci SA Jr, Wallston KA, Hummon NP. Assessment of patient satisfaction in activities of daily living using a modified Stanford Health Assessment Questionnaire. Arthritis Rheum 1983;26:1346-53.

20. Nicklin J, Cramp F, Kirwan J, Greenwood R, Urban M, Hewlett $S$. Measuring fatigue in RA: A cross sectional study to evaluate the BRAF multi-dimensional questionnaire, visual analogue and numerical rating scales. Arthritis Care Res (Hoboken). 2010 Jun 25. [Epub ahead of print]

21. Ware JE Jr, Sherbourne CD. The MOS 36-item short-form health survey (SF-36). I. Conceptual framework and item selection. Med Care. 1992; 30: 473-83.

22. Wolfe F, Michaud K, Pincus T. A composite disease activity scale for clinical practice, observational studies, and clinical trials: the patient activity scale (PAS/PAS-II). J Rheumatol 2005; 32: 2410-5.

23. Bergman MJ, Yazici Y, Hines P, Raghupathi K, Maclean R. An index of only patient-reported outcome measures, routine assessment of patient index data 3 (RAPID3), in two abatacept clinical trials: similar results to disease activity score (DAS28) and other RAPID indices that include physician-reported measures. Rheumatology (Oxford). 2008; 47: 345-9. 